The Agriculturists 18(1): 26-30 (2020) ISSN 2304-7321 (Online), ISSN 1729-5211 (Print)

A Scientific Journal of Krishi Foundation

Indexed Journal

DOI: https://doi.org/10.3329/agric.v18i1.49456

\title{
Survey on Foot and Root Rot Disease of Betel Vine (Piper betle L.) under Prevailing Environmental Condition
}

\author{
Md. Hafizur Rahman ${ }^{1}$, Md. Rafiqul Islam², F. M. Aminuzzaman², \\ Abdul Latif ${ }^{3}$ and Habibur Rahman ${ }^{4}$ \\ ${ }^{1}$ Regional Agricultural Research Station, BARI, Cumilla, Bangladesh; ${ }^{2}$ Dept. of Plant Pathology and \\ 3Dept. of Entomology, Sher-e-Bangla Agricultural University, Dhaka, Bangladesh; ${ }^{4}$ Dept. of Plant \\ Pathology, Patuakhali Science and Technology University, Patuakhali, Bangladesh \\ *Corresponding author and Email: kbdmhrahman@gmail.com
}

Received: 23 September 2019

Accepted: 25 June 2020

\begin{abstract}
A field survey was conducted to find out the incidence of foot and root rot of betel vine caused by Sclerotium rolfsii under prevailing environmental condition in major betel vine growing areas of Bangladesh. The areas were Gouranadi, Kaligonj, Mirpur, Mohanpur and Sitakunda Upazila under the district of Barisal, Jhenaidah, Kushtia, Rajshahi and Chittagong, respectively. The incidence of foot and root rot disease varied remarkably and ranged from 4.53 to $15.46 \%$ in different upzillas. The maximum incidence of $15.46 \%$ was recorded from Gouranadi where soil $\mathrm{pH}$ was 5.4 , ambient temperature was around $32^{\circ} \mathrm{C}$, relative humidity was $82 \%$ and light intensity was $53 \times 100$ lux. The lowest incidence of the disease was observed as $4.53 \%$ from Sitakunda where soil $\mathrm{pH}$ was 6.6 , ambient temperature was $28^{\circ} \mathrm{C}$, RH was $72 \%$ and light intensity was $74 \times 100 l u x$. The incidence of foot and root rot of betel vine was high in the areas where soil $\mathrm{pH}$ and light intensity were low and temperature and relative humidity were high.
\end{abstract}

Keywords: Betel vine, environment factors, foot and root rot, incidence

\section{Introduction}

Betel vine (Piper betle L.) is grown in tropical regions including Bangladesh, is a kind of creeper leaf belonging to the family Piperaceae. The leaf is consumed by man and woman by chewing, either alone or with betel nut, slaked lime (calcium hydroxide) and different flavourings condiments. It is cultivated largely is an important cash crop of Bangladesh. This perennial crop is found to be infected by various diseases of which powdery mildew, leaf rot, and foot and rot caused by Phytophthora parasitica and Colletotrichum capsici, Sclerotium rolfsii, respectively are the major diseases and are seemed to be the foremost constraints for cultivation of the crop (Goswami et al. 2002). Among the diseases foot and root rot caused by Sclerotium rolfsii is the most devastating disease that decreases the production of betel leaf to a great extent (Sayeeduzzaman, 1988; Islam, 2005). Humid and moist shaded conditions are favourable for growth of betel vine which also conducive for foot and root rot disease development (Goswami et al., 2002). Although some information on the control measure of the above mentioned diseases are available but influence of environmental factors on disease 
development and aspects of epidemiology have not been studied in the country so far. So, attempts have been made to study on incidence of foot and root rot of betel vine caused by $S$. rolfsii under prevailing environmental condition in major betel vine growing areas of Bangladesh.

\section{Materials and Methods}

The survey was conducted at five selected major betel vine growing areas of Bangladesh. The areas were Gouranadi, Kaligonj, Mirpur, Mohanpur and Sitakunda Upazilas under the districts of Barisal, Jhenaidah, Kushtia, Rajshahi and Chittagong, respectively. Five betel vine gardens (barojes) of each Upazila were visited thrice in a year for recording data. The scheduled was prepared based on variations in ambient temperature, relative humidity and rainfall during the survey period. Data were collected during late summer (August), late winter (February) and mid-summer (May) seasons of the years 2015 to 2017 . From each baroj, an area of approximately $1000 \mathrm{~m}^{2}$ were selected for data collection. Cultivars available in those areas were considered for investigation. Nine visits were made to each garden during the survey periods. Plants were selected randomly from the central part of the garden. Altogether 100 plants of each garden and 500 plants of each location were considered for the survey.

The incidence of the disease was computed based on the following formula:

Percent disease incidence $=$

Number of infected plant in the area covered

Number of inspected plant

Data on environmental factors were collected using digital hygro thermometer, soil $\mathrm{pH}$ and moisture meter and lux meter. Soil $\mathrm{pH}$ and light intensity in garden were recorded using a Survey Instrument (Model: 4 in 1: AMT-300). Air temperature and relative humidity were determined by Digital Hygro Thermometer (Model: SH-110, G H Zeal ltd., London SW 19
3UU England). Pooled data of five barojes per location were collected during the surveys in late summer (August), late winter (February) and mid-summer (May).

The pathogens associated with the foot and root rot disease of betel vine were isolated from the collected diseased samples from major betel vine growing areas of the selected Upazilas of Bangladesh following tissue planting method (Tuite, 1969). The diseased basal stems were thoroughly washed with tap water to remove soil and sand particles. After washing infected plant parts were cut into small pieces $(5 \mathrm{~cm})$ from advancing end of the lesions. The cut pieces were surface sterilized with $1.0 \%$ chlorox $(\mathrm{NaOCl})$ for 5 minutes, and rinsed with sterilized water for 3 times. Surface sterilized plant pieces were plated on PDA media in $90 \mathrm{~mm}$ petridishes and incubated at room temperature $\left(25 \pm 2^{\circ} \quad \mathrm{C}\right)$ for 3-5 days and examined daily for any fungal growth. Growing cottony mycelium was transfer to PDA plates to purify and multiply. The characteristics were compared with appropriate key book (Ellis, 1971) and identified as isolates of $S$. rolfsii. The study was conducted in laboratory of Department of Plant Pathology at Sher-e-Bangla Agricultural University, Bangladesh.

\section{Results and Discussion}

The fungus isolated from diseased betel vine samples was identified as Sclerotium rolfsii based on mycological characteristics (Fig. 1).

\subsection{Incidence of foot and root rot disease under prevailing environmental factors}

The environmental factors viz. soil $\mathrm{pH}$, ambient temperature, relative humidity and light intensity showed remarkable impact on the incidence of foot and root rot disease of betel vine (Figs. 2\&3).

3.2 Disease incidence at different level of soil pH The disease incidence decreased gradually with the increase of soil $\mathrm{pH}$ level. The highest disease incidence of $15.46 \%$ was recorded at soil $\mathrm{pH}$ of 5.4 at Gouranadi Upazila. The lowest disease 
incidence was recorded from Sitakunda, where the soil $\mathrm{pH}$ was maximum of 6.6. The results reveal that low $\mathrm{pH}$ favored the development of the disease (Fig. 2). The relationship between incidence of foot and root rot of betel vine and soil $\mathrm{pH}$ was linear and negative $(\mathrm{r}=-0.9909)$.

\subsection{Air temperature}

In case of air temperature, the highest disease incidence of $15.46 \%$ was recorded at $32.61^{\circ} \mathrm{C}$ in

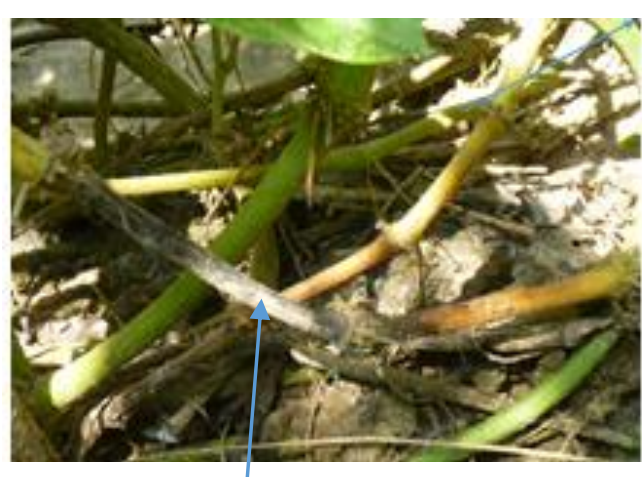

Infected betel vine

(A)
Gouranadi followed by $12.26 \%$ at $31.13^{\circ} \mathrm{C}$ in Mirpur, Rajshahi, respectively. The lowest disease incidence of $4.53 \%$ was recorded at $28.78^{\circ} \mathrm{C}$ in Sitakunda. The higher disease incidence was observed while the temperature was above $30^{\circ} \mathrm{C}$ (Fig. 3). A significant and positive correlation $(\mathrm{r}=0.988316)$ between air temperature and foot and root rot incidence was observed.

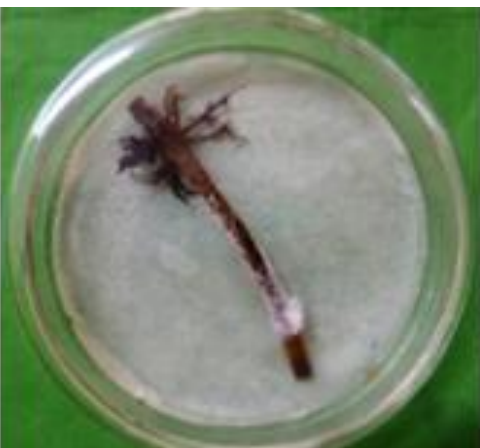

A piece of infected part of plant put on moisture blotter paper in petri-plate for pathogen grow

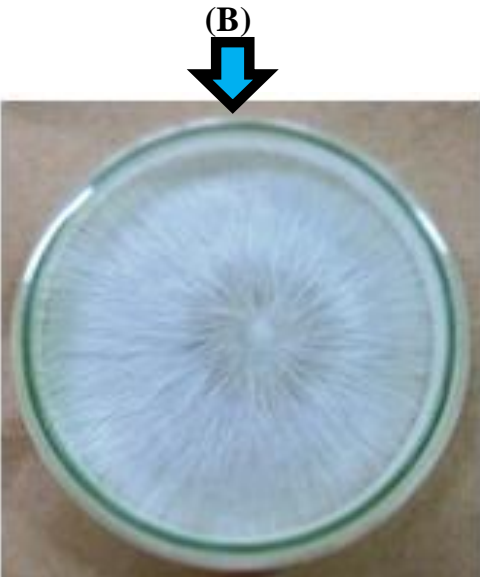

Pure culture of Sclerotium rolfsii on PDA media

(C)

(D)

Figure 1. Infected betel vine vines (A), vine piece on PDA media (B), pure culture(C) and sclerotia (D) of Sclerotium rolfsii 


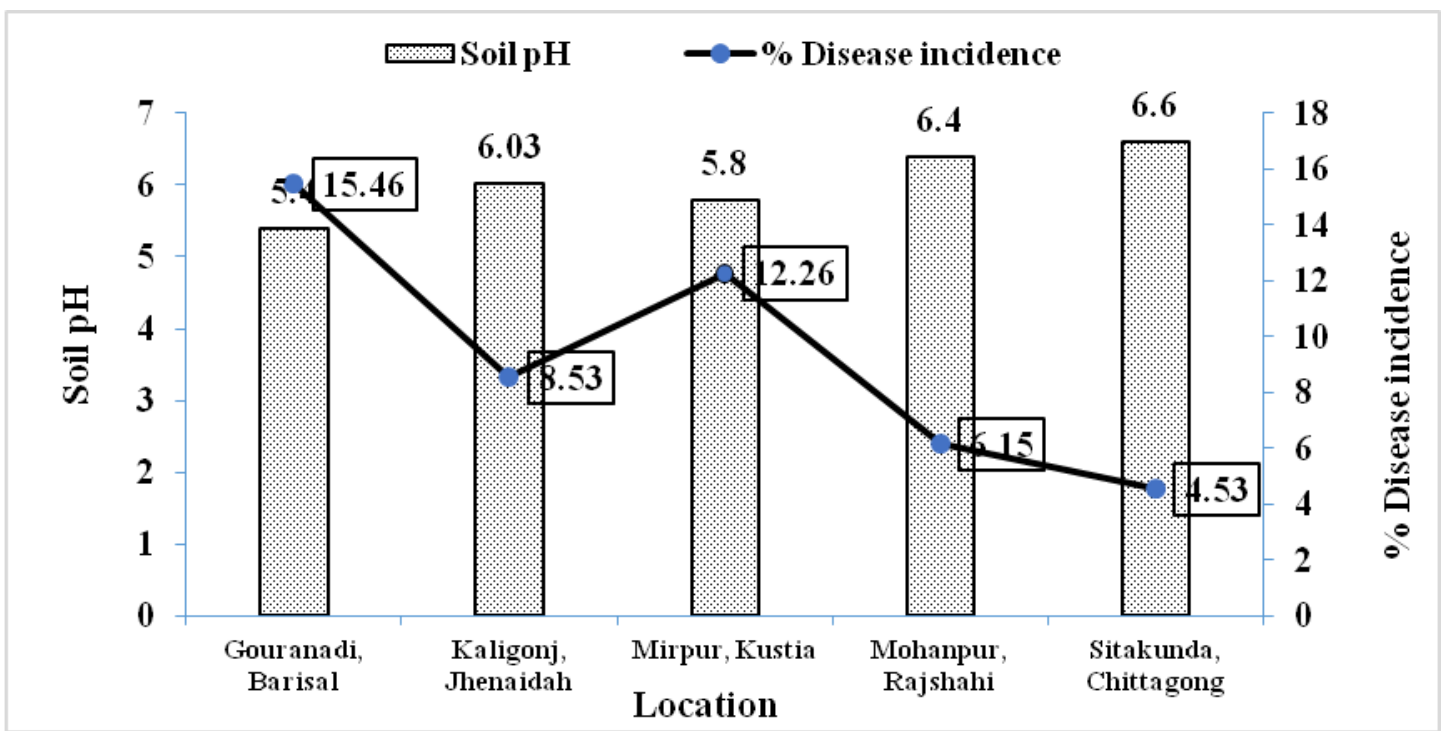

Figure 2. Effect of soil $\mathrm{pH}$ on the incidence of foot and root rot disease of betel vine

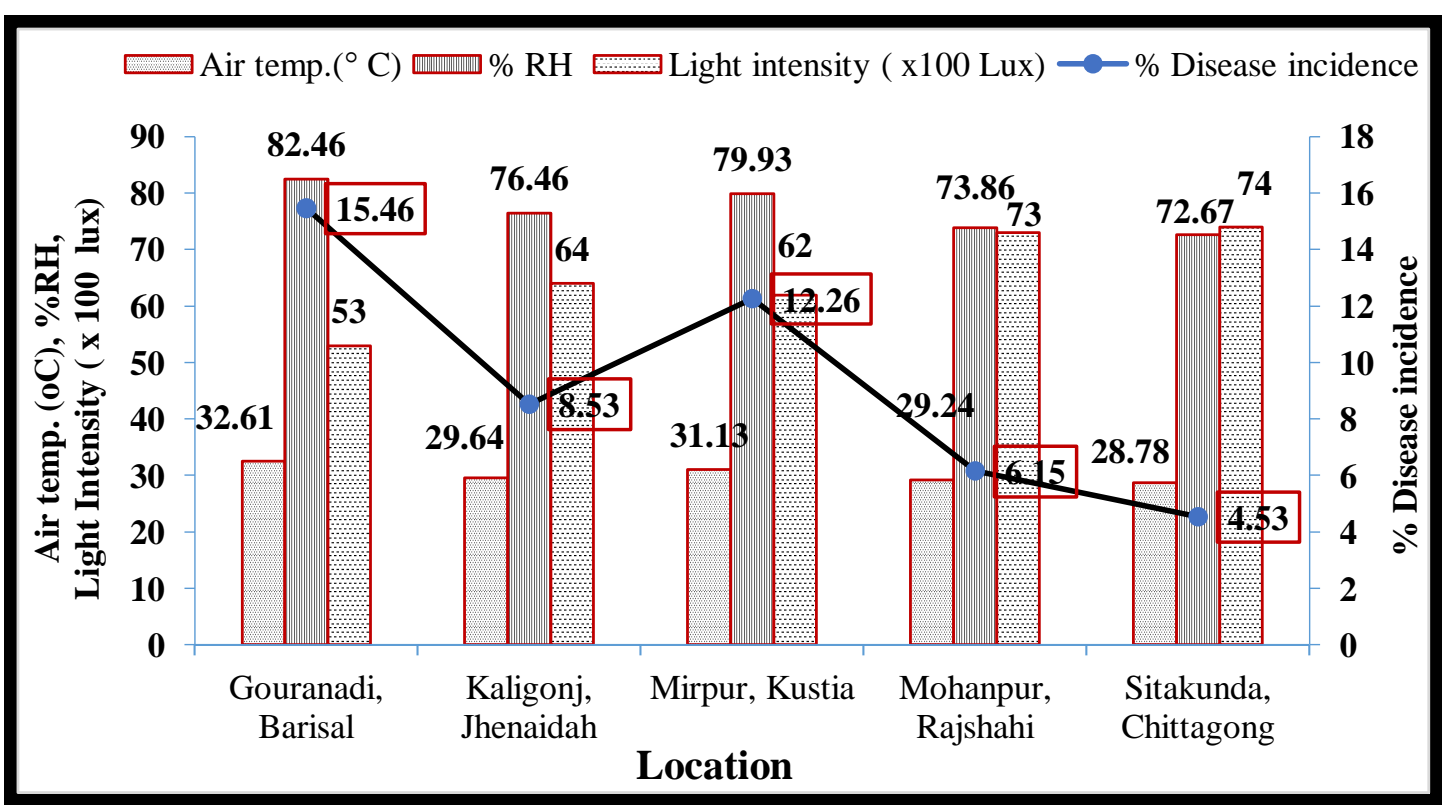

Figure 3. Effect of different weather factors on the incidence of foot and root rot disease of betel vine

\subsection{Relative humidity}

In case of relative humidity, it was revealed that the higher humidity favored the disease development. The disease gradually decreased with the decrease of relative humidity. A significant positive correlation $(r=0.9987)$ was existed between relative humidity and foot and root rot disease of betel vine (Fig. 3)

\subsection{Light intensity}

Comparatively low light intensity favored the development of foot and root rot disease of betel 
vine. The highest disease incidence of $15.46 \%$ was recorded while the light intensity was $53 \times$ 100 lux at Gouranadi Upazila followed by $12.26 \%$ disease incidence in Mirpur Upazila at $62 \times 100$ lux light intensity. The lowest disease incidence of $4.53 \%$ was recorded from Sitakunda at $74 \times 100$ lux light intensity preceded by $6.15 \%$ disease incidence at $73 \times 100$ lux in case of Mohanpur Upazila (Fig. 3). There existed negative correlation $(\mathrm{r}=-0.97215)$ between disease incidence and light intensity.

The findings of the survey reveal that low soil $\mathrm{pH} \&$ light intensity and high air temperature \& relative humidity were favourable for the development of foot and root rot disease of betel vine and vice versa. The variations in disease incidence may be attributed to the variations of environmental factors like soil $\mathrm{pH}$, ambient temperature, light intensity and relative humidity in the surveyed Upzilas.

Similar findings were also reported by other researchers. Anonymous (2004-2005 \& 20052006) and Maiti and Sen (1982) reported that temperature, relative humidity and rainfall played an important role in the development of foot and root rot of betel vine. Mollah (2012) reported that the incidence and severity of foot and root rot disease was the highest at $29^{\circ} \mathrm{C}$ and $85 \% \mathrm{RH}$ and the incidence was lowest in Satkhira district at around $18.7^{\circ} \mathrm{C}$ temperature and $75 \%$ RH. According to Punja (1985), temperature was the principal limiting factor in the geographic distribution of $S$. rolfsii. Maximum disease occurs at $25-35^{\circ} \mathrm{C}$ which was also optimum range for mycelia growth and sclerotia germination of the fungus.

\section{Conclusions}

The findings of the survey revealed that the areas where soil $\mathrm{pH}$ and light intensity were low and temperature and relative humidity were high, the incidence of foot and root rot of betel vine was high. The disease was significantly favoured by high temperature $\left(32.61^{\circ} \mathrm{C}\right)$, low soil $\mathrm{pH}(\mathrm{pH}$ 5.4), Low light intensity $(53 \times 100 \mathrm{lux})$ and high relative humidity $(82.46 \%)$. The results show that higher disease incidence was found in warmer environment.

\section{References}

Anonymous 2004-2005 \& 2005-2006. Biennial Report. All India Networking Project on Betel vine. National Research Centre for Medicinal and Aromatic Plants, Boriavi, Anand, Gujarat, India. 168p.

Ellis M.B. 1971. Dematiceous Hyphomycetes. CMI, Kew, Boco, Surrey, England. 608p.

Goswami B.K., Kader K.A., Rahman M.L., Islam M.R., Malaker P.K. 2002. Development of leaf spot of betel vine caused by Colletotrichum capsici. Bangladesh J. Pl. Path., 18(1\&2): 39-42.

Islam M.R. 2005. An integrate approach for the management of phomosis blight and fruit rot of eggplant. PhD. Thesis. Department of Plant Pathology, BAU, Mymensingh, Bangladesh, Pp. 45-46.

Maiti S., Sen C. 1982. Incidence of major diseases of betel vine in relation to weather. Indian Phytopath., 35:14-17.

Mollah M.I. 2012. Investigation on The Leaf Rot and Foot and Root Rot of betel vine (Piper betel L.) in Satkhira district of Bangladesh. MS Thesis, Dept. of Plant Pathology, Sher-e-Bangla Agricultural University, Sher-e-Bangla Nagar, Dhaka1207, Bangladesh. 7p.

Punja Z.K. 1985. The biology, ecology and control of Sclerotium rolfsii. Ann. Rev. Phytopath., 23: 97-127.

Tuite J. 1969. Plant Pathological Methods. Fungi and Bacteria Burgess Pub. Co., Minneapolis, Minn. USA., 293p. 